\title{
The presence of Microlobius foetidus cause changes in the antioxidant defense of Urochloa decumbens?
}

\author{
Silva, CB. ${ }^{a *}$, Rondon, JN. ${ }^{b}$, Souza, PF. ${ }^{b}$, Oliveira, AMR. ${ }^{c}$, Santos, GO. ${ }^{d}$, Kulik, JD. ${ }^{a}$, Lima, $C{ }^{a}{ }^{a}$, \\ Kerber, VA. ${ }^{a}$, Dias, JFG. ${ }^{a}$, Zanin, SMW. ${ }^{a}$, Miguel, $O$ G. $^{a}$ and Miguel, MD. ${ }^{a}$ \\ a Departamento de Farmácia, Universidade Federal do Paraná - UFPR, \\ Avenida Lothario Meissner, 632, CEP 80210-170, Curitiba, PR, Brazil

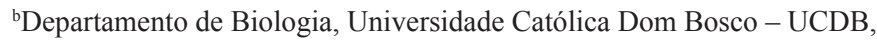 \\ Rua Eliseu Ramos de Mendonça, s/n, CEP 79117-900, Campo Grande, MS, Brazil

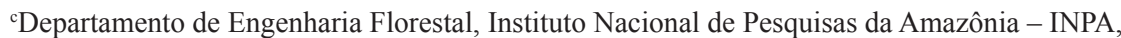 \\ Avenida André Araújo, 2936, CEP 69060-000, Manaus, AM, Brazil \\ dDepartamento de Botânica, Universidade Federal do Paraná - UFPR, \\ Rua Francisco Heráclito dos Santos, 210, CEP 81531-970, Curitiba, PR, Brazil \\ *e-mail: cris.mpj@gmail.com
}

Received: September 13, 2013 - Accepted: April 17, 2014 -Distributed: August 31, 2015

(With 2 figures)

\begin{abstract}
Urochloa decumbens (Stapf) R. D. Webster (Poaceae) is an exotic species with has spread rapidly through the Cerrado area of Pantanal, Mato Grosso do Sul, Brazil. It has covered the soil aggressively turning it into cultivated pastures. Thus, it has become a challenge to protect native areas due its capacity of exclusion of native species. It has been observed that Microlobius foetidus (Jacq.) M.Sousa \& G.Andrade species (Fabaceae) shows a dominant pattern over the development of $U$. decumbens. This work shows that $M$. foetidus interfere on the natural growth of $U$. decumbens within $10 \mathrm{~m}$ ratio. Between 15 and $20 \mathrm{~m}$, it was observed an increase of Importance Value index (IVI) and Relative cover (RC) values. It was also observed a variation on the antioxidant defense system of $U$. decumbens within $10 \mathrm{~m}$ ratio from M. foetidus. The enzymes superoxide dismutase, catalase and peroxidase present higher levels of activity then those found for glutathione reductase. This data indicates that M. foetidus may have an effect on U. decumbens, increase the activity of antioxidant enzymes. This effect probably happens as means to neutralize the toxic effects of the oxygen generated due to the presence of allelochemicals, which increases oxidative stress.
\end{abstract}

Keywords: antioxidant enzymes, signal grass, garlic stick, competition.

\section{A presença de Microlobius foetidus causa alteraçõess na defesa antioxidante de Urochloa decumbens?}

\section{Resumo}

Urochloa decumbens (Stapf) R. D. Webster (Poaceae) é uma espécie exótica que se expandiu rapidamente no Cerrado do Pantanal de Mato Grosso do sul, e cobre o solo de maneira agressiva convertendo a vegetação natural em pastagens cultivadas e se tornando um desafio para o controle em áreas protegidas devido a sua capacidade de excluir espécies nativas. Observações demonstraram que a espécie Microlobius foetidus (Jacq.) M.Sousa \& G.Andrade (Fabaceae) apresenta padrões de dominância, interferindo no desenvolvimento de $U$. decumbens e alterações na fitofisionomia e sistema de defesa antioxidante desta espécie foram investigados. Nossos estudos demonstraram que M. foetidus interfere no crescimento de $U$. decumbens nos primeiros 10 metros de distância, sendo que aos 15 e 20 metros, é verificado um aumento nos valores de IVI e CR. Alterações no sistema de defesa antioxidante de $U$. decumbens também foram verificados nos indivíduos amostrados até 10 metros de distância. Superóxido dismutase, catalase e peroxidase foram provavelmente as enzimas cruciais envolvidas na neutralização de espécies reativas de oxigênio, uma vez que apresentaram maiores níveis de atividade em comparação com outras enzimas, tais como glutationa redutase. Os dados indicam que a proximidade de $U$. decumbens as áreas onde se encontram populações de $M$. foetidus, aumentam a atividade das enzimas antioxidantes. Este efeito provavelmente ocorre como meio para neutralizar os efeitos tóxicos do oxigênio gerado, devido à presença de aleloquímicos, o que aumenta o estresse oxidativo.

Palavras-chave: enzimas antioxidantes, capim brachiaria, pau- alho, competição. 


\section{Introduction}

Human occupation in Pantanal environment introduced a new fauna and flora, breaking the natural balance among the different native species, and the biodiversity has been threatened as the natural structure of the community has been changed. About 176 exotic species are known in Brazil within terrestrial environments (Brasil, 2006).

Exotics species have grown rapidly at the Cerrado of Pantanal. Among them, two species have predominated: Urochloa decumbens and Urochloa humidicola (Rendle) Morrone \& Zuloaga. These two species are aggressive and they have been used to change the native vegetation into pastures. It has been reported to be a challenge to avoid that these herbs invade the Pantanal protected areas (Matos and Pivello, 2009).

Microlobius foetidus subsp. paraguensis (Jacq.) M. Sousa \& G. Andrade (Fabaceae), which is popularly known as garlic stick, is a tree that can reach up to $18 \mathrm{~m}$ (Pott and Pott, 1994). It appears quite naturally in modifies areas in the Pantanal, Mato Grosso do Sul and the Chaco of Porto Murtinho. It grows again very easily after cutting and burning. Leaves also exude strong garlicky odor by the production of volatile oils and local population use the leaves such a natural repellent (Silva et al., 2014).

Macias et al. (2007) also reported that through millions of years of evolution, environmental pressure has ensured that each plant species ends up with its particular solution to the survival problem, thus creating enormous biodiversity. Several morphological and biochemical adaptations have arisen through evolution to solve this problem and ensure plant survival, with a kind of chemical warfare based on toxic secondary metabolite production, storage and, eventually, release into the environment being one important strategy.

In the past, for many years Reactive oxygen species (ROS) were considered as dangerous molecules which must be maintained at low level in cells. However, recently this point of view has been changed. It has been shown that ROS can also play an important role in plant defense against oxidative explosion and can serve as markers of the certain stages of development, such as formation of tracheids and the cross-link in cell walls, lignifications, and programmed cell death and also serve as signaling/alarm molecules in regulation of gene expression process (Schützendübel and Polle, 2002; Sytar et al., 2013).

Changes in growth and antioxidant defense of plants submitted to chemical compounds liberated to the environment by others species have already been reported (Bailly et al., 2008; Pergo and Ishii-Iwamoto, 2011).

Thus, this study was undertaken to investigate the relationship between the oxidative stress in $B$. decumbens with the the predominance of Microlobius foetidus in an area of the Pantanal of Mato Grosso do Sul.

\section{Material and Methods}

\subsection{Phytosociological parameters}

Studies were performed in an Cerrado area from Pantanal, Mato Grosso do Sul, in June 2011, on the coordinates $19^{\circ} 29^{\prime} 16,20^{\prime \prime} \mathrm{S}$ and $57^{\circ} 02^{\prime} 35,50^{\prime \prime} \mathrm{W}$. A voucher of $M$. foetidus was deposited on herbarium at the Botanic Museum from Curitiba ( $\left.n^{\circ} 21739\right)$.

The Phytosociological study was conduced in a pasture area with $300 \mathrm{~m}^{2}$, and 50 individuals of $M$. foetidus (5-15 height meters). Ten plots were distributed in the east-west, with a distance difference of $0,5,10,15$ and 20 meters from $M$. foetidus from north to south.

For visual evaluation of species coverage, was observed litter (decomposing plant material), uncovered soil (US), absolute cover (AC), absolute frequency (AF), relative cover $(\mathrm{RC})$, relative frequency (RF), Importance Value index (IVI), decomposing plant material (DPM), Uncover Soil (US) and Total of individuals (TI). The results was calculated according to Brandão et al. (1998) and Lara et al. (2003).

Then five individuals of $U$. decumbens were removed, identified and stored within in a Styrofoam box with ice and taken to the laboratory for the evaluation of antioxidant enzymes.

\subsection{Enzymatic assays}

To prepare the enzyme extracts solution, $50 \mathrm{mg}$ of each part were crushed with liquid nitrogen. The resultant powder was homogenized with $50 \mathrm{mM}$ sodium phosphate buffer ( $\mathrm{pH}$ 7.0), 2 mM Ethylenediamine tetraacetic acid (EDTA) and Polyvinylpyrrolidone (PVP) 1,0\% (w/v). The liquid was filtered and kept at $-18{ }^{\circ} \mathrm{C}$ for further use (Marques and Xavier- Filho, 1991). The enzymatic solutions were prepared at $4{ }^{\circ} \mathrm{C}$. The total amount of proteins within the analyzed species was determined using the method described by Bradford (1976). The average protein of the extracts was determined by comparison with a calibration curve of albumin from Bovine serum albumin (BSA) at $594 \mathrm{~nm}$.

Catalase activity (CAT) was measured in a medium containing $67 \mathrm{mM} \mathrm{K}$-phosphate ( $\mathrm{pH} 7.0), 10 \mathrm{mM} \mathrm{H}_{2} \mathrm{O}_{2}$, and $0.1-0.4 \mathrm{mg}$ protein of enzyme extract. The consumption of $\mathrm{H}_{2} \mathrm{O}_{2}$ was monitored at $240 \mathrm{~nm}\left(\varepsilon, 0.036 \mathrm{mM}^{-1} \mathrm{~cm}^{-1}\right)$ (Aebi, 1984).

Peroxidase activity (POD) was measured in a medium containing $25 \mathrm{mM} \mathrm{K}$-phosphate ( $\mathrm{pH} 6.8), 10 \mathrm{mM} \mathrm{H}_{2} \mathrm{O}_{2}$, $2.6 \mathrm{mM}$ guaiacol, and $0.1-0.4 \mathrm{mg}$ protein of enzyme extract. Tetraguaicol formation $\left(\varepsilon, 25.5 \mathrm{mM}^{-1} \mathrm{~cm}^{-1}\right)$ was measured at $470 \mathrm{~nm}$ (Putter, 1974).

Superoxide dismutase (SOD) activity was measured according to Giannopolitis and Ries (1977). The medium contained $50 \mathrm{mM}$ K-phosphate $(\mathrm{pH} 7.8) 6.5 \mathrm{mM}$ methionine, $150 \mu \mathrm{M}$ nitro blue tetrazolium (NBT), $4 \mu \mathrm{M}$ riboflavin, and $0.02-0.1 \mathrm{mg}$ protein of enzyme extract. The reaction was started by switching on a light (micro light quantum $\times \mathrm{m}^{2} \times \mathrm{s}^{-1}$ ) and illuminating the medium for $20 \mathrm{~min}$ at $30^{\circ} \mathrm{C}$. One unit (U) of SOD activity, was defined as the amount of enzyme required to cause $50 \%$ inhibition of the NBT photoreduction rate read at $560 \mathrm{~nm}$, and the results were expressed as U of SOD mg protein ${ }^{-1}$.

The Glutathione reductase activity (GSR) was measured in a medium containing $50 \mathrm{mM}$ potassium phosphate buffer ( $\mathrm{pH}$ 8.0), $2 \mathrm{mM}$ EDTA, $0.5 \mathrm{mM}$ Glutathione disulfide (GSSG), $0.15 \mathrm{mM}$ Reduced NADP (NADPH), and $0.1-0.4 \mathrm{mg}$ protein of the enzyme extract. The NADPH 
oxidation rate was monitored at $340 \mathrm{~nm}\left(\varepsilon, 6,2 \mathrm{mM}^{-1} \mathrm{~cm}^{-1}\right)$ according to Foyer and Halliwell (1976).

The lipid peroxidation (LP) was measured in a medium containing (Trichloroacetic acid) TCA $0.1 \%$, thiobarbituric acid $0.5 \%$, and $0.1-0.4 \mathrm{mg}$ protein of the enzyme extract (Gomes-Júnior et al., 2006). The results were measured at $534 \mathrm{~nm}$ and the activity was expressed as percentage of lipid peroxidation.

The total concentration of carbohydrates in leaves was determined according to Moraga et al. (2006), using the phenol sulfuric method. The leaves of each sample, had their central nervure taken and were crushed in liquid nitrogen. After that, $300 \mathrm{mg}$ of the mass was extracted with $3 \mathrm{ml}$ of ethanol $80 \%$ on an assay tube. The assay tube was agitated and warmed at $60^{\circ} \mathrm{C}$ during $30 \mathrm{~min}$ in a water bath and then centrifuged at $4000 \mathrm{rpm}$ for another $30 \mathrm{~min}$ at $4^{\circ} \mathrm{C}$.

After the centrifugation, $1 \mathrm{ml}$ of the extract was transferred to assay tubes with $1 \mathrm{ml}$ of chloroform and $1 \mathrm{ml}$ of deionized water. The mixtures were left for $45 \mathrm{~min}$. The pigments migrated to the organic phase and the carbohydrates remaining in the aqueous phase. $200 \mu \mathrm{l}$ of the aqueous phase were diluted with $1 \mathrm{ml}$ of deionized water. $500 \mu 1$ of this solution was transferred to assay tubes containing $500 \mu \mathrm{l}$ of phenol (5\%), and $25 \mu \mathrm{l}$ of concentrated sulfuric acid. The mixture was agitated using a vortex and the measurement was read at $485 \mathrm{~nm}$. To have the total soluble carbohydrates concentration values we have used the calibration curve: $\mathrm{y}=0,0081 \mathrm{x}+0,0744$ (where: $\mathrm{y}=$ absorbance; $\mathrm{x}=$ carbohydrates concentration; $\mathrm{R}^{2}=0,9988$ ).

To determination of proline, $1 \mathrm{ml}$ of the samples were treated with $5 \mathrm{ml}$ of a $3 \%$ sulfo salicylic acid solution. Next, the mixture was centrifuged during $5 \mathrm{~min}$ at $3000 \mathrm{rpm}$ at room temperature. $1 \mathrm{ml}$ of the supernatant of each sample was transferred to assay tubes and $1 \mathrm{ml}$ of acid ninhidrin was added followed by $1 \mathrm{ml}$ of glacial acetic acid. The assay tubes were kept at $100^{\circ} \mathrm{C}$ for hour in water bath. After that the samples were refrigerated in ice and the red complex was extracted with $2 \mathrm{ml}$ of toluene (vortex for 30 seconds). After reaching room temperature, the absorbance of the toluene red-complex solution was measured at $520 \mathrm{~nm}$, according to Bates et al. (1973). The proline concentration measurements were done using the calibration curve: $\mathrm{y}=0.0959 \mathrm{x}-0.2147$ (where: $\mathrm{y}=$ absorbance; $\mathrm{x}=$ proline concentration; $\left.\mathrm{R}^{2}=0.9926\right)$.
To evaluate each sample, three measures was collected and the variation data was analyzed. If any difference was detected by the F analysis, we change to the Dunnet analysis, with $5 \%$ probability. If any demanded parameter did not match, non-parametric analysis were performed such as Kruskal-Wallis instead of variance analysis and Mann-Whitney instead of Dunnet analysis.

\section{Results and Discussion}

The data gathered showed that Microlobius foetidus affects the development of Urochloa decumbens. The parameters: uncover soil (18.2\%) and decomposing plant material $(60.8 \%)$ were very high where grows nearby M. foetidus $(0 \mathrm{~m})$. Such an influence was also detected till 5 to $10 \mathrm{~m}$, and the porcentage of undercover soil and decomposing plant material increases with distance between $U$. decumbens and M. foetidus (Table 1).

The average numbers of individuals were also influenced by the distance of $U$. decumbens from M. foetidus. The number of the sample individuals of $U$. decumbens decreases as the distance from $M$. foetidus decreases. These data are reinforced when IVI and RC of the 5 distances are compared (Table 1).

At the initial point $(0 \mathrm{~m})$ the IVI (15.02) and RC (3.08) are lower than at $5 \mathrm{~m}$ (IVI-31.49; CR-14.46). This effect was also observed as the distance from $M$. foetidus increases, $10 \mathrm{~m}$ (IVI-45.,11; RC-25.23), 15 m (IVI- 53.04; RC-27.38), and $20 \mathrm{~m} 10$ (IVI- 55.35; RC- 29.85) (Table 1). There was no significant difference between 15 - $20 \mathrm{~m}$ distances within the studied parameters, thus establishing a $15 \mathrm{~m}$ perimeter of influence of $M$. foetidus over $U$. decumbens.

$B$. decumbens showed significant difference of total proteins concentration for the distances observed. Individuals from nearby $M$. foetidus ( 0 meters) displayed a higher total proteins concentration $\left(25 \mu \mathrm{g} . \mathrm{g}^{-1}\right)$ when compared to the others. Comparing individuals from all distances studied: $5 \mathrm{~m}\left(23.8 \mu \mathrm{g} \cdot \mathrm{g}^{-1}\right), 10 \mathrm{~m}\left(17.9 \mu \mathrm{g} \cdot \mathrm{g}^{-1}\right), 15 \mathrm{~m}\left(12.7 \mu \mathrm{g} \cdot \mathrm{g}^{-1}\right)$ and $20 \mathrm{~m}\left(12.5 \mu \mathrm{g} \cdot \mathrm{g}^{-1}\right)$, it can be observed the decreasing of the total protein concentration in opposition to the increasing distance of $U$. decumbens from M. foetidus (Figure 1).

The evaluation of the CAT, POD, SOD (Figures 1b-d) GSH (Figure 2a) enzyme activities showed an effect similar to that one observed with the total protein concentration. The M. foetidus nearest individuals displayed higher

Table 1. Phytosociological Parameters of $U$. decumbens at nearby $M$. foetidus in the cerrado area.

\begin{tabular}{ccccccccc}
\hline $\begin{array}{c}\text { Distance from } \\
\text { M. foetidus (meters) }\end{array}$ & $\begin{array}{c}\text { DOM* } \\
\mathbf{( \% )}\end{array}$ & $\mathbf{U S} * \mathbf{( \% )}$ & $* \mathbf{T I}$ & $\mathbf{A C} *$ & AF* & RC* & RF* & IVI* \\
\hline 0 & 60.8 & 18.2 & 155 & 10.00 & 0.17 & 3.08 & 11.94 & 15.02 \\
5 & 43.5 & 15.7 & 221 & 47.00 & 0.21 & 14.46 & 17.03 & 31.49 \\
10 & 32.2 & 12.4 & 258 & 82.00 & 0.33 & 25.23 & 19.88 & 45.11 \\
15 & 15.4 & 10.7 & 331 & 89.00 & 0.73 & 27.38 & 25.50 & 53.04 \\
20 & 10.1 & 8.1 & 333 & 97.00 & 1.00 & 29.85 & 25.65 & 55.35 \\
\hline
\end{tabular}

US: Uncover Soil, TI: Total of individuals, AC: Absolute Cover, AF: Absolute Frequency, RC: Relative cover, RF: Relative Frequency, IVI: Importance Value Index. *DOM: Dead Organic Matter. 
antioxidant activity then the farther ones as displayed at Figures 1 and 2 .

A major percentage of per oxidation of lipids was observed for the individuals closest to $M$. foetidus (0 meters). This effect decreases with the distance from M. foetidus as shown in Figure 2b.
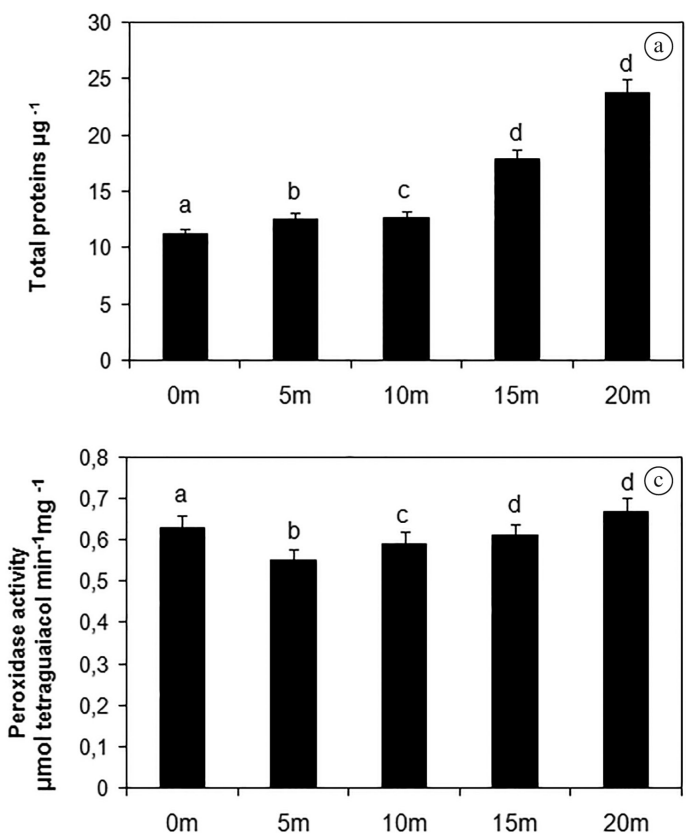

Figure 1. Total amount of Proteins (a), Catalase (b), Peroxidase (c) and superoxide dismutase activities (d) of U. decumbens, collected in different distances from $M$. foetidus. The means followed by the same letter from the control have no significant difference among them, according to Dunnet test $(\mathrm{p}<0.05)$.
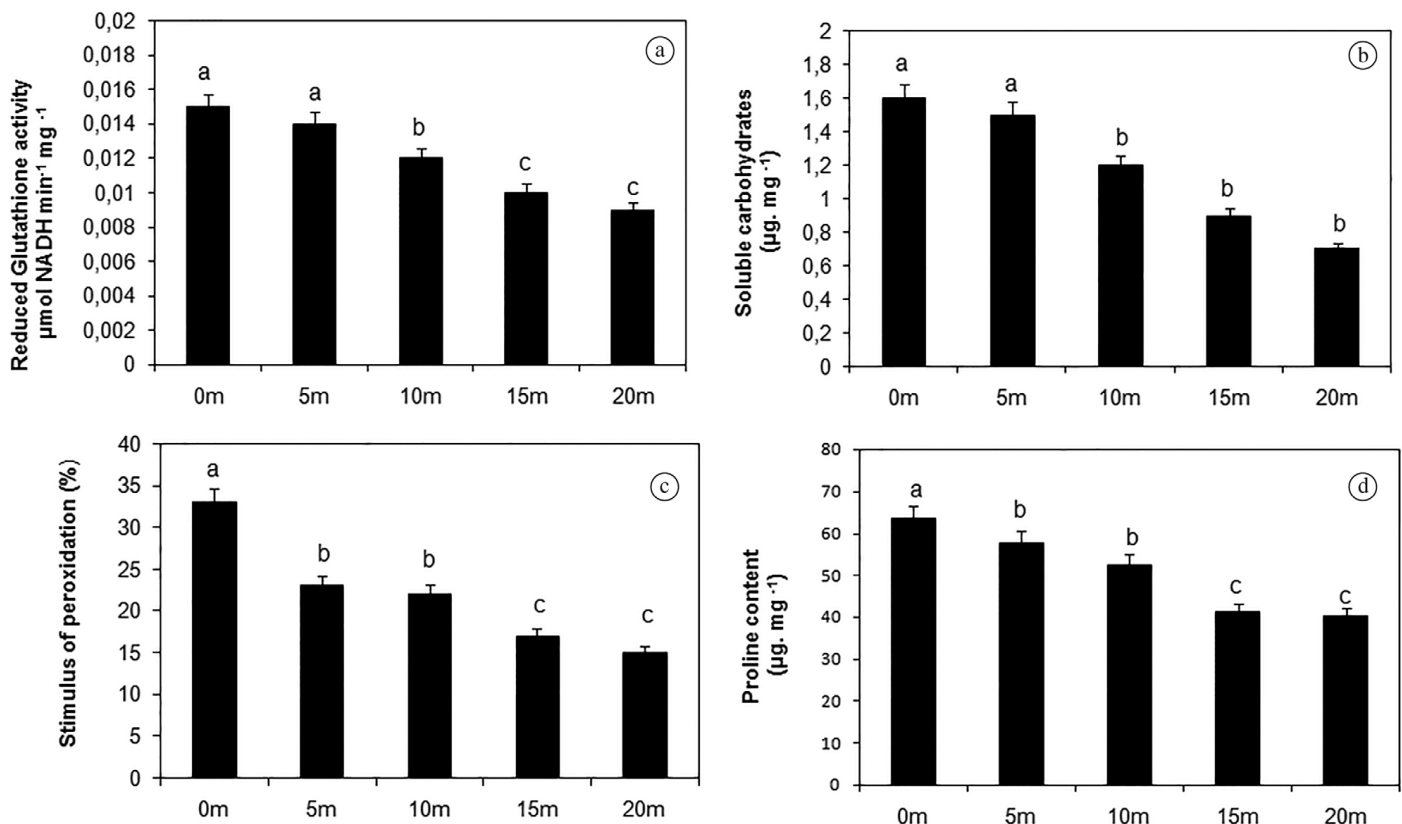

Figure 2. Glutathione reductase activity (a), stimulation of lipid per oxidation (b), soluble carbohydrates (c) and proline concentration (d); of $U$. decumbens collected in different distances from M. foetidus. The means followed by the same letter from the control have no significant difference among them according to Dunnet test $(\mathrm{p}<0.05)$. 
studied, it can be inferred that individuals that grow nearby $M$. foetidus can suffer interference from the compounds freed to the environment by the material originated from dead leaves of this species.

The proline concentration within leaves of $B$. decumbens also displays variation as a function of the distance from M. foetidus. It was observed that individuals from $0 \mathrm{~m}$ (43.4 $\left.\mu \mathrm{g} . \mathrm{g}^{-1}\right), 5 \mathrm{~m}\left(57.8 \mu \mathrm{g} . \mathrm{g}^{-1}\right)$ and $10 \mathrm{~m}\left(52.4 \mu \mathrm{g} . \mathrm{g}^{-1}\right)$ displayed a higher proline concentration then that observed for the distances of $15 \mathrm{~m}\left(41.2 \mu \mathrm{g} \cdot \mathrm{g}^{-1}\right)$ and $20 \mathrm{~m}\left(40.3 \mu \mathrm{g} \cdot \mathrm{g}^{-1}\right)$ (Figure 2d). This effect happens probably due the need for protection against lipid peroxidation, activating or even removing directly the oxygen reactive species.

$U$. decumbens is the species most often used for the fast expansion process of cultivated pastures in the Cerrado Pantaneiro, where it aggressively covers the soil turning the natural vegetation into cultivated pastures.

\section{Conclusion}

There is not much information about M. foetidus species, however "in situ" observations has shown that this species grows in mono specific population, establishing a strong intra-specific competition, eliminating even others species in areas of dirty field and clean field cerrados. Another important characteristic that favors this species is that after a short period of rain, the plant produces a lot of flowers, increasing the number of seeds. This increase in seed production, makes possible the chance of some germinate and become mature plants, favoring the predominance of this species.

Our results show that the $M$. foetidus species interfere on the development of $B$. decumbens, reducing the number of individuals within 10 meters radium from this specie. Observations in large distances ( 15 and $20 \mathrm{~m}$ ) show that the values $\mathrm{RC}$ and $\mathrm{RF}$ are quite similar, thus $M$. foetidus interferes on the $U$. decumbens only within a 10 meters radium.

The changes in germination and the growth of plants, as well as changes of antioxidant defense activity by the influence of compounds liberated in to the environment have already been reported (Pergo and Ishii-Iwamoto, 2011; Silva et al., 2009). However, few experiments have been done at natural environments that could help to prove these effects in nature. Del Moral et al. (1978) compared the competitive and chemical effects of two Eucalyptus species, demonstrating that the growth inhibition of other species was due to the liberation of leachates from the leaves of Eucalyptus baxteri.

Reactive Oxygen species (ROS), mainly hydrogen peroxide $\left(\mathrm{H}_{2} \mathrm{O}_{2}\right)$ and the superoxide radical $\left(\mathrm{O}_{2}^{-}\right)$, may react with several molecules generated by cells causing oxidative damage which can interfere with the regular development of the cells (Marino et al., 2009; Silveira et al., 2003). The plants protect their cells and sub-cell invasive geophyte species. Organs from cytotoxic effects of the ROS with the help of antioxidant enzymes such as super oxide dismutase (SOD), glutathione reductase (GSR), catalase (CAT) among others (Scandalios, 1993; Mittler, 2002).

Comparing the changes of the antioxidant defense activity of $U$. decumbens, it was observed that this activity increases as the distance from $M$. foetidus decreases. These results indicate that $U$. decumbens suffers an oxidative stress, increasing the levels of ROS as a counterpart to the inhospitable environment.

The enzyme activities analyzed show that SOD and CAT display higher activity, thus, having the main role of the ROS neutralization in $U$. decumbens. This specie also has secondary enzymes such as peroxidases. The peroxidases may appear in several forms and are involved in several physiologic processes such as ionic or covalent interactions with polymers from the cellular wall, thus having a role at the biosynthetic pathway of lignin from the cellular wall (Passardi et al., 2005; Quiroga et al., 2000). In the other hand, GSH has no significant role in the elimination of $\mathrm{H}_{2} \mathrm{O}_{2}$ in $U$. decumbens due its low level of activity when compared to other analyzed enzymes.

The physiologic roles of these enzymes at germination, growth and development of the plants are not completely known. It was suggested that these enzymes play a major role at the hydration of tissues, cells enlarging, nitrogen accumulation (Rodriguez-Concepción and Beltrán, 1995; Tranbarger et al., 1991), and lipid degradation (Feussner et al., 1997).

The increasing lipid per oxidation activity induced by ROS, shown on $U$. decumbens happens as a result of the changes of lipid molecules what also affects the structure of the cell membrane (Moore and Siedow, 1991; Baker and Orlandi, 1995; Thaler, 1999; Porta and Rocha-Sosa, 2002; Blokhina et al., 2003). Peroxidation of the poli-insaturated lipid acids decreases the membranes fluidity, thus loosing cellular content or organelles, together with secondary damage to the membrane proteins (Halliwell, 2006).

When the antioxidant defense system of $U$. decumbens individuals is changed as well as the tillers number, decreases as indicated by the percentage of uncovered soil (Table 1), the soluble carbohydrates can be dislocated from senescent leaves to other parts of the plant, favoring the increase of soluble carbohydrates in individuals that are growing near of $\mathrm{M}$. foetidus.

The main reason for the presence of carbohydrates in plants is the source of energy (Palma et al., 2002). Soluble sugars seem to assume a dual role with respect to ROS. Soluble sugars can be involved in ROS-producing metabolic pathways. In reverse, soluble sugars can also feed NADPH-producing metabolic pathways, such as the oxidative pentose-phosphate (OPP) pathway, which can contribute to ROS scavenging (Russell et al., 2002).

Proline is a protein generator amino acid with exceptional function to the rigid conformation, and it is essential for primary metabolism (Szabados and Savoure, 2010). Proline accumulation has been observed in dry conditions (Choudhary et al., 2005), high salt concentration (Yoshiba et al., 1995), high light intensity and UV radiation (Saradhi et al., 1995), heavy metals (Schat et al., 1997), 
oxidative stress (Yang et al., 2009) and biotic stress (Fabro et al., 2004; Haudecoeur et al., 2009).

It is believed that proline accumulation has a role on the adaptation pathways of plants living under stress conditions. It is been proposed that proline acts like an osmolyte and it is a way to the carbon and nitrogen accumulation (Hare and Cress, 1997).

The amount of proline in the study of $U$. decumbens individuals was also influenced by the neighborhood of M. foetidus species. The high level of proline is useful to protect against lipid peroxidation (Molinari et al., 2007) removing ROS directly or activating the antioxidant defense system (Carvalho et al., 2013).

It seems that increasing the production of antioxidant enzymes demands more energy from $U$. decumbens, contributing to the reduction of vegetal cover as means to reduce its growth. The grasses are among the invading species with high capability to colonize the forests and denser "cerrado sensu stricto" like areas such as those occurring in the Pantanal. The capacity of $U$. decumbens to inhibit, native species has been reported (Matos and Pivello, 2009; Oliveira, 2004). It has been a challenge to control $U$. decumbens in protected areas, especially after a burning, which is a common fact at dry seasons.

Oxidative stress, which frequently or stress, may cause denaturation of functional and structural proteins (Smirnoff, 1998). As a consequence, these diverse environmental stresses often activate similar cell signaling pathways (Knight, 2000; Shinozaki and Yamaguchi-Shinozaki, 2000; Zhu, 2001; Zhu, 2002) and cellular responses, such as the production of stress proteins, up regulation of antioxidants and accumulation of compatible solutes (Vierling and Kimpel, 1992; Zhu et al., 1997; Cushman and Bohnert, 2000; Wang et al., 2003).

Stress-induced ROS accumulation is counteracted by enzymatic antioxidant systems that include a variety of scavengers, such as SOD, POD and CAT and non-enzymatic low molecular metabolites, such as ASH, GSH (Mittler et al., 2004). In addition, proline can now be added to an elite list of non-enzymatic antioxidants that microbes, animals, and plants need to counteract the inhibitory effects of ROS (Chen and Dickman, 2005).

Plant stress tolerance may therefore be improved by the enhancement of in vivo levels of antioxidant enzymes. The above said antioxidants found in almost all cellular compartments, demonstrating the importance of ROS detoxification for cellular survival (Dalton et al., 1999).

In agro-eco systems, the allelochemicals liberated by plants which induce an increasing effect to the oxidative stress may contribute to discover natural compounds that can be used to control invading species (Inderjit and Duke, 2003). In fact, it is already known that some commercial herbicides induce oxidative stress until cell death.

This is a consequence of the interference on the flow of electrons from photo system II (PSII) or, yet, by the inhibition of the biosynthesis of antioxidant compounds such as the carotenoids (Kruse et al., 2006). It is reasonable to suggest that $M$. foetidus have a high potential to inhibit the $U$. decumbens invasion through the induction of the oxidative stress during its growth phase.

The compounds produced in M. foetidus leaves can be investigated as a means to establish a control plan for $U$. decumbens at protected areas. Beyond the primary mechanisms of oxidative stress induced by M. foetidus, the data we found suggest that, during the growth phase, the investigated antioxidant enzyme activities increases and they neutralize the oxygen reactive species, leaving in situ plants more vulnerable to dysfunction and cell death.

This data indicates that M. foetidus may have an effect on $U$. decumbens, increasing antioxidant activity. This effect probably happens as means to neutralize the toxic effects of the oxygen generated due to the presence of allelochemicals, which increases oxidative stress.

\section{Acknowledgements}

We are thankful to Paraná Federal University - Paraná Brazil, and Capes/ Reuni for the research grant.

\section{References}

AEBI, H., 1984. Catalase in vitro. Methods in Enzymology, vol. 105, p. 121-126. http://dx.doi.org/10.1016/S0076-6879(84)050163. PMid:6727660.

BAILLY, C., EL-MAAROUF-BOUTEAU, H. and CORBINEAU, F., 2008. From intracellular signaling networks to cell death: the dual role of reactive oxygen species in seed physiology. Comptes Rendus Biologies, vol. 331, no. 10, p. 806-814. http://dx.doi. org/10.1016/j.crvi.2008.07.022. PMid:18926495.

BAKER, CJ. and ORLANDI, EW., 1995. Active oxygen in plant pathogenesis. Annual Review of Phytopathology, vol. 33, no. 1, p. 299-321. http://dx.doi.org/10.1146/annurev.py.33.090195.001503. PMid:18999963.

BATES, LS., WALDREN, RP. and TEARE, ID., 1973. Rapid determination of free proline for water - stress studies. Plant and Soil, vol. 39, no. 1, p. 205-207. http://dx.doi.org/10.1007/ BF00018060.

BLOKHINA, O., VIROLAINEN, E. and FAGERSTEDT, KV., 2003. Antioxidants, oxidative damage and oxygen deprivation stress: a review. Annals of Botany, vol. 91, p. 179-194. http:// dx.doi.org/10.1093/aob/mcf118. PMid:12509339.

BRADFORD, MM., 1976. A rapid and sensitive method for the quantitation of microgram quantities of protein utilizing the principle of protein-dye binding. Analytical Biochemistry, vol. 72 , no. $1-2$, p. $248-254$. http://dx.doi.org/10.1016/00032697(76)90527-3. PMid:942051.

BRANDÃO, M., BRANDÃO, H. and LACA-BUENDIA, JP., 1998. A mata ciliar do Rio Sapucaí, município de Santa Rita do Sapucaí-MG: fitossociologia. Daphne, vol. 8, p. 36-48.

Brasil. Ministério do Meio Ambiente, 2006. Espécies exóticas invasoras: situação brasileira. Brasília: Ministério do Meio Ambiente/ Secretaria de Biodiversidade e Florestas. 24 p.

CARVALHO, K., CAMPOS, MK., DOMINGUES, DS., PEREIRA, LFP. and VIEIRA, LGE., 2013. The accumulation of endogenous proline induces changes in gene expression of several antioxidant 
enzymes in leaves of transgenic Swingle citrumelo. Molecular Biology Reports, vol. 40, no. 4, p. 3269-3279. http://dx.doi. org/10.1007/s11033-012-2402-5. PMid:23292076.

CHEN, C. and DICKMAN, MB., 2005. Proline suppresses apoptosis in the fungal pathogen Colletotrichum trifolii. Proceedings of the National Academy of Sciences of the United States of America, vol. 102, no. 9, p. 3459-3464. http://dx.doi. org/10.1073/pnas.0407960102. PMid:15699356.

CHOUDHARY, NL., SAIRAM, RK. and TYAGI, A., 2005. Expression of delta1-pyrroline-5-carboxylate synthetase gene during drought in rice (Oryza sativa L.). Indian Journal of Biochemistry \& Biophysics, vol. 42, no. 6, p. 366-370. PMid:16955737.

CUSHMAN, JC. and BOHNERT, HJ., 2000. Genomic approaches to plant stress tolerance. Current Opinion in Plant Biology, vol. 3, no. 2, p. 117-124. http://dx.doi.org/10.1016/S1369-5266(99)000527. PMid: 10712956.

DALTON, TP., SHERTZER, HG. and PUGA, A., 1999. Regulation of gene expression by reactive oxygen. Annual Review of Pharmacology and Toxicology, vol. 39, no. 1, p. 67-101. http:// dx.doi.org/10.1146/annurev.pharmtox.39.1.67. PMid:10331077.

DEL MORAL, R., WILLIS, RJ. and ASHTON, DH., 1978. Suppression of coastal heath vegetation by Eucalyptus baxteri. Australian Journal of Botany, vol. 26, no. 2, p. 203-219. http:// dx.doi.org/10.1071/BT9780203.

FABRO, G., KOVÁCS, I., PAVET, V., SZABADOS, L. and ALVAREZ, ME., 2004. Proline accumulation and AtP5CS2 gene activation are induced by plant-pathogen incompatible interactions in Arabidopsis. Molecular Plant-Microbe Interactions: MPMI, vol. 17, no. 4, p. 343-350. http://dx.doi.org/10.1094/ MPMI.2004.17.4.343. PMid:15077666.

FEUSSNER, I., BALKENHOHL, TJ., PORZEL, A., KÜHN, H. and WASTERNACK, C., 1997. Structural elucidation of oxygenated storage lipids in cucumber cotyledons. Implication of lipid body lipoxygenase in lipid mobilization during germination. The Journal of Biological Chemistry, vol. 272, no. 34, p. 21635-21641. http:// dx.doi.org/10.1074/jbc.272.34.21635. PMid:9261186.

FOYER, CH. and HALLIWELL, B., 1976. The presence of glutathione and glutathione reductase in chloroplasts: a proposed role in ascorbic acid metabolism. Planta, vol. 133, no. 1, p. 2125. http://dx.doi.org/10.1007/BF00386001. PMid:24425174.

GIANNOPOLITIS, CN. and RIES, SK., 1977. Superoxide dismutases: I. Occurrence in higher plants. Plant Physiology, vol. 59, no. 2, p. 309-314. http://dx.doi.org/10.1104/pp.59.2.309. PMid:16659839.

GOMES-JUNIOR, RA., MOLDES, CA., DELITE, FS., POMPEU, GB., GRATÃO, PL., MAZZAFERA, P., LEA, PJ. and AZEVEDO, RA., 2006. Antioxidant metabolism of coffee cell suspension cultures in response to cadmium. Chemosphere, vol. 65, no. 8, p. 1330-1337. http://dx.doi.org/10.1016/j.chemosphere.2006.04.056. PMid:16762393.

HALLIWELL, B., 2006. Reactive species and antioxidants. Redox biology is a fundamental theme of aerobic life. Plant Physiology, vol. 141, no. 2, p. 312-322. http://dx.doi.org/10.1104/ pp.106.077073. PMid:16760481.

HARE, PD. and CRESS, WA., 1997. Metabolic implications of stress-induced proline accumulation in plants. Plant
Growth Regulation, vol. 21, no. 2, p. 79-102. http://dx.doi. org/10.1023/A:1005703923347.

HAUDECOEUR, E., PLANAMENTE, S., CIROU, A., TANNIÈRES, M., SHELP, BJ., MORÉRA, S. and FAURE, D., 2009. Proline antagonizes GABA-induced quenching of quorum-sensing in Agrobacterium tumefaciens. Proceedings of the National Academy of Sciences of the United States of America, vol. 106, no. 34, p. 14587-14592. http://dx.doi.org/10.1073/pnas.0808005106. PMid:19706545.

INDERJIT, SO. and DUKE, SO., 2003. Ecophysiological aspects of allelopathy. Planta, vol. 217, no. 4, p. 529-539. http://dx.doi. org/10.1007/s00425-003-1054-z. PMid:12811559.

KNIGHT, H., 2000. Calcium signaling during abiotic stress in plants. International Review of Cytology, vol. 195, no. 1, p. 269-325.

KRUSE, ND., VIDAL, RA. and TREZZI, MM., 2006. Curvas de resposta e isobolograma como forma de descrever a associação de herbicidas inibidores do fotossistema II e da síntese de carotenóides. Planta Daninha, vol. 24, no. 3, p. 579-587. http:// dx.doi.org/10.1590/S0100-83582006000300022.

LARA, JFR., MACEDO, JF. and BRANDÃO, M., 2003. Plantas daninhas em pastagens de várzeas no Estado de Minas Gerais. Planta Daninha, vol. 21, no. 1, p. 11-20. http://dx.doi.org/10.1590/ S0100-83582003000100002.

MACÍAS, FA., GALINDO, JLG. and GALINDO, JCG., 2007. Evolution and current status of ecological phytochemistry. Phytochemistry, vol. 68, no. 22-24, p. 2917-2936. http://dx.doi. org/10.1016/j.phytochem.2007.10.010. PMid:18023828.

MARINO, D., PUCCIARIELLO, C., PUPPO, A. and FRENDO, P., 2009. The redox state a referee of the Legume-Rhizobia symbiotic game. Advances in Botanical Research, vol. 52, p. 115-151. http:// dx.doi.org/10.1016/S0065-2296(10)52005-6.

MARQUES, MR. and XAVIER-FILHO, J., 1991. Enzymatic and inhibitory activities of cashew tree gum exudate. Phytochemistry, vol. 30, no. 5, p. 1431-1433. http://dx.doi.org/10.1016/00319422(91)84179-V.

MATOS, DMS. and PIVELLO, VR., 2009. O impacto das plantas invasoras nos recursos naturais de ambientes terrestres: alguns casos brasileiros. Ciencia e Cultura, vol. 61, p. 27-30.

MITTLER, R., 2002. Oxidative stress, antioxidants and stress tolerance. Trends in Plant Science, vol. 7, no. 9, p. 405-410. http:// dx.doi.org/10.1016/S1360-1385(02)02312-9. PMid:12234732.

MITTLER, R., VANDERAUWERA, S., GOLLERY, M. and VAN BREUSEGEM, F., 2004. Reactive oxygen gene network of plants. Trends in Plant Science, vol. 9, no. 10, p. 490-498. http://dx.doi.org/10.1016/j.tplants.2004.08.009. PMid:15465684.

MOLINARI, HBC., MARUR, CJ., DAROS, E., CAMPOS, MKF., CARVALHO, JFPR., BESPALHOK- FILHO, JC., PEREIRA, LFP. and VIEIRA, LGE., 2007. Evaluation of the stress-inducible production of proline in transgenic sugar cane (Saccharum spp.): osmotic adjustment, chlorophyll fluorescence and oxidative stress. Physiologia Plantarum, vol. 130, no. 2, p. 218-229. http://dx.doi. org/10.1111/j.1399-3054.2007.00909.x.

MOORE, AL. and SIEDOW, JN., 1991. The regulation and nature of the cyanide-resistant alternative oxidase of plant mitochondria. Biochimica et Biophysica Acta, vol. 1059, no. 2, p. 121-140. http:// dx.doi.org/10.1016/S0005-2728(05)80197-5. PMid:1883834. 
MORAGA, SP., ESCOBAR, R. and VALENZUELA, AS., 2006. Resistance to freezing in three Eucalyptus globules Labill subspecies. Electronic Journal of Biotechnology, vol. 9, no. 3, p. 310-314. http://dx.doi.org/10.2225/vol9-issue3-fulltext-24.

OLIVEIRA, MD., 2004. Introdução de espécies: uma das maiores causas de perda de biodiversidade. Corumbá: Embrapa Pantanal. 234 p.

PALMA, J.M., SANDALIO, L. M., CORPAS, F.J., ROMEROPUERTAS, M.C., MCCARTHY, I. and DEL RÍO, LA., 2002. Plant proteases, protein degradation, and oxidative stress: role of peroxisomes. Plant Physiology and Biochemistry, vol. 405, p. 21-530.

PASSARDI, F., COSIO, C., PENEL, C. and DUNAND, C., 2005. Peroxidases have more functions than a Swiss army knife. Plant Cell Reports, vol. 24, no. 5, p. 255-265. http://dx.doi.org/10.1007/ s00299-005-0972-6. PMid:15856234.

PERGO, EM. and ISHII-IWAMOTO, EL., 2011. Changes in energy metabolism and antioxidant defense systems during seed germination of the weed species Ipomoea triloba L. and the responses to allelochemicals. Journal of Chemical Ecology, vol. 37, no. 5, p. 500-513. http://dx.doi.org/10.1007/s10886-0119945-0. PMid:21503619.

PORTA, H. and ROCHA-SOSA, M., 2002. Plant lipoxygenases. Physiological and molecular features. Plant Physiology, vol. 130, no. 1, p. 15-21. http://dx.doi.org/10.1104/pp.010787. PMid:12226483.

POTT, A. and POTT, VJ., 1994. Plantas do pantanal. Corumbá: EMBRAPA. 234 p.

PUTTER, J., 1974. Peroxidase. In BERGMEYER, HU. (Ed.). Methods of enzymatic analysis. Weinhan: Verlag Chemie. p. 685-690.

QUIROGA, M., GUERRERO, C., BOTELLA, MA., BARCELÓ, A., AMAYA, I., MEDINA, MI., ALONSO, FJ., FORCHETTI, SM., TIGIER, H. and VALPUESTA, V., 2000. A tomato peroxidase involved in the synthesis of lignin and suberin. Plant Physiology, vol. 122, no. 4, p. 1119-1128. http://dx.doi.org/10.1104/pp.122.4.1119. PMid:10759507.

RODRÍGUEZ-CONCEPCIÓN, M. and BELTRÁN, JP., 1995. Repression of the pea lipoxygenase gene loxg is associated with carpel development. Plant Molecular Biology, vol. 27, no. 5, p. 887-899. http://dx.doi.org/10.1007/BF00037017. PMid:7766879.

RUSSELL, JW., GOLOVOY, D., VINCENT, AM., MAHENDRU, P., OLZMANN, JA., MENTZER, A. and FELDMAN, EL., 2002. High glucose-induced oxidative stress and mitochondrial dysfunction in neurons. FASEB Journal : Official Publication of the Federation of American Societies for Experimental Biology, vol. 16, no. 13, p. 1738-1748. http://dx.doi.org/10.1096/fj.011027com. PMid:12409316.

SARADHI, PP., ALIAARORA, S. and PRASAD, KV., 1995. Proline accumulates in plants exposed to UV radiation and protects them against UV induced peroxidation. Biochemical and Biophysical Research Communications, vol. 209, no. 1, p. 1-5. http://dx.doi.org/10.1006/bbrc.1995.1461. PMid:7726821.

SCANDALIOS, JG., 1993. Oxygen stress and superoxide dismutase. Plant Physiology, vol. 101, no. 1, p. 7-12. PMid:12231660.

SCHAT, H., SHARMA, SS. and VOOIJS, R., 1997. Heavy metalinduced accumulation of free proline in a metal-tolerant and a nontolerant ecotype of Silene vulgaris. Physiologia Plantarum, vol.
101, no. 3, p. 477-482. http://dx.doi.org/10.1111/j.1399-3054.1997. tb01026.x.

SCHÜTZENDÜBEL, A. and POLLE, A., 2002. Plant responses to abiotic stresses: heavy metal-induced oxidative stress and protection by mycorrhization. Journal of Experimental Botany, vol. 53, no. 372, p. 1351-1365. http://dx.doi.org/10.1093/jexbot/53.372.1351. PMid:11997381.

SHINOZAKI, K. and YAMAGUCHI-SHINOZAKI, K., 2000. Molecular responses to dehydration and low temperature: differences and cross-talk between two stress signaling pathways. Current Opinion in Plant Biology, vol. 3, no. 3, p. 217-223. http:// dx.doi.org/10.1016/S1369-5266(00)00067-4. PMid:10837265.

SILVA, CB., SIMIONATTO, E., HESS, SC., PERES, MTLP., SIMIONATTO, EL., WISNIEWSKI JUNIOR, A., POPPI, NR., FACCENDA, O., CÂNDIDO, ACS. and SCALON, SPQ., 2009. Composição química e atividade alelopática do óleo volátil de Hydrocotyle bonariensislam (Araliaceae). Quimica Nova, vol. 32, p. 2373-2376. http://dx.doi.org/10.1590/S0100-40422009000900026.

SILVA, CB., SIMIONATTO, E., GEBARA, SS., RÉ-POPPI, N., PERES, MTLP., RECH, KS., SANTOS, GO., DIAS, JFG., ZANIN, SMW., MIGUEL, MD., MIGUEL, OG., 2014. Sensitivity of Brachiaria decumbens and Ipomoea cordifolia to cyclic polysulfides from leaves of Microlobius foetidus. Allelopathy Journal, vol. 33, no. 1, p. 213-226.

SILVEIRA, JAG., VIÉGAS, RA., ROCHA, IM., MOREIRA, ACOM., MOREIRA, RA. and OLIVEIRA, JTA., 2003. Proline accumulation and glutamine synthetase activity are increased by saltinduced proteolysis in cashew leaves. Journal of Plant Physiology, vol. 160, no. 2, p. 115-123. http://dx.doi.org/10.1078/0176-161700890. PMid:12685027.

SMIRNOFF, N., 1998. Plant resistance to environmental stress. Current Opinion in Biotechnology, vol. 9, no. 2, p. 214-219. http:// dx.doi.org/10.1016/S0958-1669(98)80118-3. PMid:9664051.

SYTAR, O., KUMAR, A., LATOWSKI, A., KUCZYNSKA, P., STRZAŁKA, K. and PRASAD, MNV., 2013. Heavy metalinduced oxidative damage, defense reactions, and detoxification mechanisms in plants. Acta Physiologiae Plantarum, vol. 35, no. 4, p. 985-999. http://dx.doi.org/10.1007/s11738-012-1169-6.

SZABADOS, L. and SAVOURÉ, A., 2010. Proline: a multifunctional amino acid. Trends in Plant Science, vol. 15, no. 2, p. 89-97. http://dx.doi.org/10.1016/j.tplants.2009.11.009. PMid:20036181.

THALER, JS., 1999. Induced resistance in agricultural crops: effects of jasmonic acid on herbivory and yield in tomato plants. Environmental Entomology, vol. 28, no. 1, p. 30-37. http://dx.doi. org/10.1093/ee/28.1.30.

TRANBARGER, TJ., FRANCESCHI, VR., HILDEBRAND, DF. and GRIMES, HD., 1991. The soybean 94-kilodalton vegetative storage protein is a lipoxygenase that is localized in paraveinal mesophyll cell vacuoles. The Plant Cell, vol. 3, no. 9, p. 973-987. http://dx.doi.org/10.1105/tpc.3.9.973. PMid:1822994

VIERLING, E. and KIMPEL, JA., 1992. Plant responses to environmental stress. Current Opinion in Biotechnology, vol. 3, no. 2, p. 164-170. http://dx.doi.org/10.1016/0958-1669(92)90147-B. PMid:1368289.

WANG, R., OKAMOTO, M., XING, X. and CRAWFORD, NM., 2003. Microarray analysis of the nitrate response in Arabidopsis roots and shoots reveals over 1,000 rapidly responding genes and 
new linkages to glucose, trehalose-6-phosphate, iron, and sulfate metabolism. Plant Physiology, vol. 132, no. 2, p. 556-567. http:// dx.doi.org/10.1104/pp.103.021253. PMid:12805587.

YANG, SL., LAN, SS. and GONG, M., 2009. Hydrogen peroxideinduced proline and metabolic pathway of its accumulation in maize seedlings. Journal of Plant Physiology, vol. 166, no. 15, p. 1694-1699. http://dx.doi.org/10.1016/j.jplph.2009.04.006. PMid:19446917.

YOSHIBA, Y., KIYOSUE, T., KATAGIRI, T., UEDA, H., MIZOGUCHI, T., YAMAGUCHI-SHINOZAKI, K., WADA, K., HARADA, Y. and SHINOZAKI, K., 1995. Correlation between the induction of a gene for delta 1-pyrroline-5-carboxylate synthetase and the accumulation of proline in Arabidopsis thaliana under osmotic stress. The Plant journal : for Cell and Molecular
Biology, vol. 7, no. 5, p. 751-760. http://dx.doi.org/10.1046/j.1365313X.1995.07050751.x. PMid:7773306.

ZHU, JK., 2001. Cell signaling under salt, water and cold stresses. Current Opinion in Plant Biology, vol. 4, no. 5, p. 401-406. http:// dx.doi.org/10.1016/S1369-5266(00)00192-8. PMid:11597497.

ZHU, JK., 2002. Salt and drought stress signal transduction in plants. Annual Review of Plant Biology, vol. 53, no. 1, p. 247-273. http://dx.doi.org/10.1146/annurev.arplant.53.091401.143329. PMid:12221975.

ZHU, JK., HASEGAWA, PM., BRESSAN, RA. and BOHNERT, HJ., 1997. Molecular aspects of osmotic stress in plants. Critical Reviews in Plant Sciences, vol. 16, no. 3, p. 253-277. http://dx.doi. org/10.1080/07352689709701950. 